\title{
REVIEW
}

\section{The natural history and treatment of non-functioning pituitary adenomas (non-functioning PitNETs)}

\author{
Maria P Yavropoulou(D1, Marina Tsoli1 ${ }^{1}$, Konstantinos Barkas², Gregory Kaltsas ${ }^{1}$ and Ashley Grossman ${ }^{3,4}$ \\ 'Endocrinology Unit, 1st Department of Propaedeutic Internal Medicine, School of Medicine, National and Kapodistrian University of Athens, \\ Athens, Greece \\ 2Department of Neurosurgery, General Hospital of Nikaia-Peiraia, Agios Panteleimon, Athens, Greece \\ ${ }^{3}$ Centre for Endocrinology, Barts and the London School of Medicine, Queen Mary University of London, London, UK \\ ${ }^{4}$ Oxford Centre for Diabetes, Endocrinology and Metabolism, University of Oxford, Oxford, UK
}

Correspondence should be addressed to M P Yavropoulou: myavropoulou@med.uoa.gr

\begin{abstract}
Non-functioning pituitary adenomas, recently alternatively termed pituitary neuroendocrine tumours (NFpitNETs), are mostly benign neoplasms that are not associated with a hormonal hypersecretory syndrome. The clinical spectrum of NFpitNETs varies from completely asymptomatic to the development of panhypopituitarism and manifestations attributed to mass effects on nearby structures. NFpitNETs follow generally an indolent course, but in 5-10\% of cases they exhibit more aggressive behaviour, characterised by rapid growth, invasiveness and early recurrence. The initial size of the adenoma, the presence of symptoms and the histological subtype are related to the natural course of NFpitNETs. Active surveillance is usually the strategy of choice in the case of an asymptomatic NFpitNET, while surgical resection is recommended in case of visual and/or neurological abnormalities or rapid tumour growth. Based on previous and emerging data, approximately $50 \%$ of patients show tumour growth, while $20 \%$ of patients with NF-macroadenomas on active surveillance may require further intervention during a follow-up period of 7 years. Adjuvant radiotherapy is usually considered for large residual tumours or recurrent and/or aggressive adenomas, but there is evidence that medical therapy, especially with cabergoline, can occasionally be beneficial, whereas newer molecular agents are under investigation. Thus, while highly effective medical therapy is awaited, a move towards a more conservative approach seems appropriate, at least until we have better molecular markers of progressiveness.
\end{abstract}

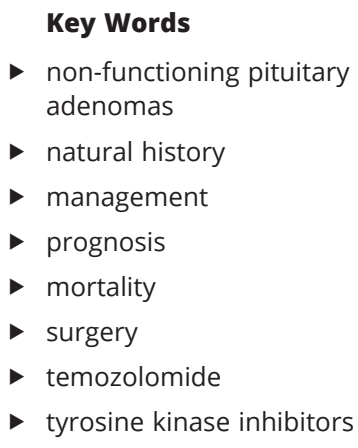

Endocrine-Related Cancer (2020) 27, R375-R390

\section{Introduction}

Non-functioning pituitary adenomas are defined as benign adenohypophyseal tumours that are not associated with evidence of hormonal hypersecretion, except for hyperprolactinaemia secondary to compression of the pituitary stalk (Drummond et al. 2019). Their diagnosis is usually made in the presence of symptoms related to mass effects and compression of nearby vital structures and/or the development of anterior hormonal deficiencies, but a significant number are increasingly incidentally diagnosed during imaging investigations performed for unrelated purposes (pituitary incidentalomas, PIs) (Scangas \& Laws 2014). Recently, pituitary adenomas have 
been suggested to be renamed pituitary neuroendocrine tumours (pitNETs) (Asa et al. 2017). The majority of these tumours follow a relatively indolent or even stable course but a subset, approximately $5-10 \%$, may exhibit a more aggressive course with rapid growth or early recurrence following initial treatment. Although non-functioning pitNETs (NFpitNETs) constitute the majority of significant sellar lesions and have distinct imaging features, occasionally distinction from other sellar pathologies may be needed in the presence of rapid growth and unusual or equivocal imaging features (Kaltsas et al. 2019).

As pitNETs are not associated with hormonal hypersecretion, their diagnosis may be significantly delayed, often being recognised when compressive symptoms to surrounding tissues occur. Thus, at the time of diagnosis, approximately $67-90 \%$ of NFpitNETs are macroadenomas, with the median age of the patients ranging between 51.5 and 65.5 years (Raappana et al. 2010). In contrast, when they are recognised as PIs, the prevalence of microadenomas is significantly higher, ranging between $10 \%$ and $38 \%$ on CT imaging and $4-20 \%$ on MRI compared to the incidence of macroadenomas (range between $0.16 \%$ on MRI and $0.3 \%$ on CT) (Freda et al. 2011).

The management of NFpitNETs includes replacement hormonal therapy in the presence of endocrine deficiencies along with surgical resection in cases of neurological abnormalities, visual impairment and/or rapid tumour growth. Radiotherapy (RT) may also be considered as adjuvant treatment to prevent further tumour growth for aggressive tumours, while the alkylating agent temozolomide (TMZ) has been introduced for highly aggressive pituitary tumours (APTs) or pituitary carcinomas (PCs) (Chatzellis et al. 2015). More recently, active surveillance has more frequently been advocated in cases without symptoms/signs of mass effect and/or significant hormonal deficiencies; this approach is particularly useful in elderly patients and patients with comorbidities (Chanson et al. 2015). The natural course of un-operated NFpitNETs is highly heterogeneous and largely depends on the initial size of the tumour (microadenoma vs macroadenoma), the diagnostic mode of discovery (incidental vs nonincidental) and the clinical presentation (symptomatic vs asymptomatic). On the other hand, the prognosis and the course of the surgically managed NFpitNETs also show a wide diversity of outcomes; increased risk of recurrence, tumour progression, hormone deficiencies and aggravation of visual field deficits, along with various rates of perioperative morbidity and mortality, are frequently reported, depending on the experience of the neurosurgeon.

Classically, assessment of proliferation markers such as the Ki-67 labelling index (LI), mitotic activity, and p53 expression have been recommended as prognostic markers for tumour aggressiveness and risk of recurrence, but more recently the WHO has especially emphasised the role of the Ki-67 LI as well as surgical and radiological factors as being most critical (Mete \& Lopes 2017).

Intense research in the field of molecular biology is currently ongoing to identify novel molecular biomarkers that could predict the biologic behaviour of these tumours in an effort to assist the clinician to properly modify the therapeutic plan and follow-up of patients with NFpitNETs. This will be vital to identify when a conservative vis-à-vis a more aggressive approach is required.

\section{Epidemiology}

NFpitNETs account for approximately $14-54 \%$ of pituitary adenomas, the second most commonly found after prolactinomas and the commonest of all macroadenomas (Ntali \& Wass 2018). In the general population, the prevalence of clinically relevant NFpitNET is $7-41.3$ cases per 100,000, based on population studies from Europe, Canada and the United States of America (Fernandez et al. 2010, Agustsson et al. 2015, Al-Dahmani et al. 2016).

In surgical series, the incidence of NFpitNETS ranges between 9 and 21\% (Nomikos et al. 2004, Losa et al. 2013). As a component of hereditary syndromes, NFpitNETs occur in patients with multiple endocrine neoplasia type 1 (MEN1) and type 4 (MEN4), and familial isolated pituitary adenomas (FIPAs). In large cohorts of patients with MEN1, pituitary tumours ranged from 14.7\% (NF-macroadenomas) (Verges et al. 2002) to $42.3 \%$ (NF-microadenomas) (de Laat et al. 2015). NFpitNETs appear to occur more frequently in MEN4 compared to MEN1, although overall MEN4 is extremely rare (Alrezk et al. 2017). In FIPAs NFpitNETs occur in less than $20 \%$ of families, but present earlier than their sporadic counterparts (Daly et al. 2006). One case of an NFpitNET has also been reported in a young adult with paraganglioma in the setting of a germline mutation in succinate dehydrogenase subunit A (SDH-A) (Dwight et al. 2013). Patients with Carney complex develop GH or PRL-GH mixed tumours but, while NFpitNETs have not been reported, clinically silent GH and IGF-1 elevations have been described (Correa et al. 2015). 


\section{Classification of NFpitNETs}

The immunohistochemical (IHC) profile of adenohypophyseal hormones along with the transcription factors related to pituitary ontogenesis (Fig. 1) (pituitary transcription factor 1 (Pit-1); steroidogenic factor 1 (SF-1); T-box family member TBX19 (T-Pit); guanine-adeninethymine-adenine binding protein 2 (GATA-2)) is currently considered the gold standard for the classification system of pitNETs (Mete \& Lopes 2017) (Table 1). In a recent pangenomic classification of pitNETs, Pit-1 appeared to be the main classification driver and Pit1-lineage was associated with DNA hypomethylation and chromosomal instability (Neou et al. 2020). Whether these alterations are linked to the biological behaviour of Pit1-lineage

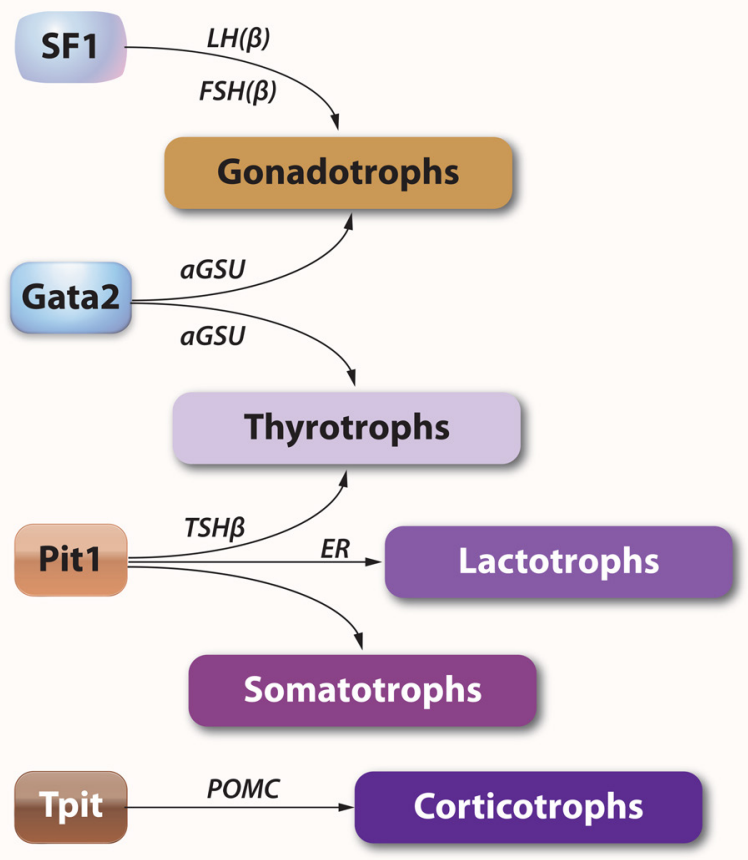

\section{Figure 1}

The role of transcription factors in the differentiation of pituitary cells. SF-1 acts as transcription factor for the differentiation of gonadotroph cells and is expressed in gonadotropinomas. GATA-2 transcription factors are also associated with the differentiation of gonadothroph, lactotroph, and thyrotrophs cells and may be pathogenetically involved in the development of the respective tumours. Pit-1 plays a role in the differentiation of somatotroph, lactotroph, and thyrotroph cells and in the development of the respective tumours. T-Pit is required for the transcription of POMC to ACTH and promotes the differentiation of corticotroph cells. SF1, steroideogenic factor 1; GATA-2, guanine-adeninethymine-adenine binding protein 2; Pit-1, pituitary transcription factor 1; T-pit, T-box family member TBX19; POMC, precursor polypeptide pro-opiomelanocortin; ACTH, adrenocorticotropic hormone; ER $\alpha$, estrogen receptor- $\alpha$ pha; FSH, follicle-stimulating hormone; $\mathrm{LH}$, luteinising hormone; aGSU, alpha subunit of G-proteins coupled receptor. tumours, paving the way towards a molecular-based prediction of aggressiveness and treatment response, is yet to be determined.

\section{Subtypes of non-functioning PitNETs}

\section{Non-functioning-silent gonadotroph adenomas}

Silent gonadotroph adenomas (sGAs) comprise the vast majority (approximately 80\%) of NFpitNETs and are characterised by focal immunostaining for $\beta$-folliclestimulating hormone ( $\beta$-FSH), $\beta$-luteinising hormone $(\beta-\mathrm{LH})$, and $\alpha$-subunit. The nuclear labelling of the SF-1 transcription factor is detected in most tumour cells and assists in confirming the diagnosis in cases with sparse or no gonadotroph hormone expression. The current definition and limitations, however, of the gonadotroph lineage were questioned in a recent multi-omic analysis of a large cohort of PitNETs (Neou et al. 2020), as the gonadotroph molecular signature was also identified in null-cell, silent corticotroph and somatotroph PitNETs.

\section{Non-functioning/silent corticotroph adenomas}

Silent corticotroph adenomas (sCAs) represent approximately 15-20\% of NFpitNETs, being the second most common type after sGAs. Histologically, they can be divided into two subtypes; type I densely granulated sCAs, showing strong ACTH immunoreactivity, and type 2 sparsely granulated sCAs, demonstrating weak and focal ACTH staining.

\section{Non-functioning/silent somatotroph adenomas}

Silent somatotroph adenomas (sSAs) represent approximately $2-4 \%$ of all pituitary adenomas (Langlois et al. 2018). Growth hormone immunostaining varies widely from very weak to strongly positive, being less than in somatotrophinomas causing acromegaly. In addition, more than 50\% of sSAs demonstrate mixed $\mathrm{GH}$ and prolactin (PRL) secretion. In cases with very low or absent GH staining, nuclear expression of the transcription factor Pit-1 is a valuable diagnostic tool, since all GH tumours express Pit-1 (Langlois et al. 2018).

\section{Non-functioning/silent thyrotroph adenomas}

Silent thyrotroph adenomas (sTAs) are extremely rare but are reported more frequently than TSH-omas (Mete \& Lopes 2017). Both sTAs and TSHomas express TSH- $\beta$, and $\alpha$-subunit, Pit- 1 and GATA-2 transcription factors, and significant membrane immunoreactivity for somatostatin receptors (SSTR)-2A and SSTR-5. 
Table 1 Classification of non-functioning pituitary neuroendocrine tumours based on hormone staining and nuclear expression of pituitary-specific transcription factors.

\begin{tabular}{|c|c|c|c|}
\hline Tumour groups & Subtypes & Transcription factors & Hormones \\
\hline PIT1 lineage & Somatotroph tumour & PIT1 & \\
\hline \multirow[t]{10}{*}{ tumour } & $\begin{array}{l}\text { Densely granulated } \\
\text { somatotroph tumour }\end{array}$ & & $\mathrm{GH}, \alpha$-subunit \\
\hline & $\begin{array}{l}\text { Sparsely granulated } \\
\text { somatotroph tumour }\end{array}$ & & $\mathrm{GH}$ \\
\hline & Lactotroph tumour & PIT1, ER- $\alpha$ & \\
\hline & $\begin{array}{l}\text { Sparsely granulated } \\
\text { lactotroph tumour }\end{array}$ & & PRL (Golgi) \\
\hline & $\begin{array}{l}\text { Densely granulated } \\
\text { lactotroph tumour }\end{array}$ & & PRL (Diffuse) \\
\hline & Acidophil stem cell tumour & & $\begin{array}{l}\text { PRLGH (variable), } \\
\alpha \text {-subunit }\end{array}$ \\
\hline & Mammosomatotroph tumour & PIT1, ER- $\alpha$ & $\mathrm{GH}, \mathrm{PRL}, \alpha$-subunit \\
\hline & Thyrotroph tumour & $\begin{array}{l}\text { PIT1, GATA2/3 } \\
\text { (Mete et al. 2019, } \\
\text { Turchini et al. } \\
\text { 2020) }\end{array}$ & $\beta$-TSH, $\alpha$-subunit \\
\hline & $\begin{array}{l}\text { Poorly differentiated PIT-1 } \\
\text { lineage tumour } \\
\text { Silent subtype } 3 \text { adenoma } \\
\text { (Formerly known) } \\
\text { Plurihormonal PIT1-positive } \\
\text { adenoma (WHO 2017) }\end{array}$ & $\begin{array}{l}\text { PIT1, ER- } \alpha, \text { GATA2/3 } \\
\text { (Mete et al. 2019, } \\
\text { Turchini et al. } \\
\text { 2020) }\end{array}$ & $\begin{array}{l}\text { Focal/scattered for } \\
\text { one or more than PIT1 } \\
\text { lineage hormones } \\
\text { (GH/PRL/ } \beta \text {-TSH); can be } \\
\text { hormone-negative }\end{array}$ \\
\hline & $\begin{array}{l}\text { Well differentiated (Mature) } \\
\text { PIT-1 lineage plurihormonal } \\
\text { tumour }\end{array}$ & $\begin{array}{l}\text { PIT1, ER- } \alpha, \text { GATA2/3 } \\
\text { (Mete et al. 2019, } \\
\text { Turchini et al. } \\
\text { 2020) }\end{array}$ & $\begin{array}{l}\text { GH (near diffuse/diffuse), } \\
\text { PRL (variable), } \beta \text {-TSH } \\
\text { (focal/variable) }\end{array}$ \\
\hline $\begin{array}{l}\text { SF1 lineage } \\
\text { tumour }\end{array}$ & Gonadotroph tumour & $\begin{array}{l}\text { SF1, ER- } \alpha, \text { GATA2/3 } \\
\text { (Mete et al. 2019, } \\
\text { Turchini et al. } \\
\text { 2020) }\end{array}$ & $\begin{array}{l}\beta \text {-FSH } \pm \beta \text {-LH; } \alpha \text {-subunit, } \\
\text { hormone negativity in } 40 \% \\
\text { of cases (Mete et al. 2019) }\end{array}$ \\
\hline \multirow[t]{4}{*}{$\begin{array}{l}\text { TPIT lineage } \\
\text { tumour }\end{array}$} & Corticotroph tumours & $\begin{array}{l}\text { TPIT; rare GATA2/3 } \\
\text { (Mete et al. 2019, } \\
\text { Turchini et al. } \\
\text { 2020) }\end{array}$ & \\
\hline & $\begin{array}{l}\text { Densely granulated } \\
\text { corticotroph tumour } \\
\text { (silent corticotroph tumour, } \\
\text { type 1) }\end{array}$ & & ACTH (diffuse and strong) \\
\hline & $\begin{array}{l}\text { Sparsely granulated } \\
\text { corticotroph tumour (silent } \\
\text { corticotroph tumouassr, } \\
\text { type 2) }\end{array}$ & & $\begin{array}{l}\text { ACTH (focal/weak, can be } \\
\text { negative) }\end{array}$ \\
\hline & Crooke cell tumour & & $\begin{array}{l}\text { ACTH (cell periphery and } \\
\text { juxtanuclear) }\end{array}$ \\
\hline $\begin{array}{l}\text { Tumours with no } \\
\text { PIT1, SF1 and } \\
\text { TPIT-lineage } \\
\text { differentiation }\end{array}$ & Null-cell tumour & $\begin{array}{l}\text { Negative for PIT1, } \\
\text { ER- } \alpha, \text { SF1, GATA2/3 } \\
\text { (Mete et al. 2019, } \\
\text { Turchini et al. } \\
\text { 2020) }\end{array}$ & $\begin{array}{l}\text { Negative for } \\
\text { adenohypohyseal } \\
\text { hormones }\end{array}$ \\
\hline $\begin{array}{l}\text { Tumours with } \\
\text { multi-lineage } \\
\text { differentiation }\end{array}$ & $\begin{array}{l}\text { Plurimorphous plurihormonal } \\
\text { tumours }\end{array}$ & $\begin{array}{l}\text { Any combination of } \\
\text { PIT1, TPIT, SF1, } \\
\text { ER- } \alpha, \text { GATA2/3 }\end{array}$ & $\begin{array}{l}\text { Any combination of } \\
\text { adenohypohyseal } \\
\text { hormones }\end{array}$ \\
\hline
\end{tabular}

Additiona

CAM5.2 with perinuclear CAM5.2 with fibrous bodies (>70\%)

CAM5.2 with scattered fibrous bodies

CAM5.2 can display scattered fibrous bodies

CAM5.2 can be negative

CAM5.2 with diffuse staining, p27 is often preserved in silent tumours

CAM5.2 with diffuse staining, p27 is often preserved in silent tumours

CAM5.2 with ring-like staining, p27 is often preserved in silent tumours (Mete et al. 2019)

CAM5.2 can be negative

\section{Multifocal pituitary neuroendocrine tumours do not qualify for this diagnosis}

ACTH, adrenocorticotropic hormone; CAM5.2, cytokeratin; ER-a, estrogen receptor alpha; FSH, follicle-stimulating hormone; GATA-2, guanine-adeninethymine-adenine binding protein 2; GH, growth hormone; LH, luteinising hormone; PIT1, pituitary transcription factor 1; PRL, prolactin; SF-1, steroidogenic factor 1; TPIT, T-box family member TBX19; TSH, thyroid stimulating hormone; WHO, World Health Organization.

https://erc bioscientifica com https://doi.org/10.1530/ERC-20-0136 


\section{Non-functioning/silent lactotroph adenomas}

Silent lactotroph adenomas (sLAs) express PRL, Pit-1 and ER- $\alpha$ (Mete \& Lopes 2017). Mono-hormonal sLAs are rare, usually presenting as silent mixed somatotrophlactotroph adenomas in Pit-1 positive tumours. sLAs are classified further into sparsely and densely granulated subtypes (Mete \& Lopes 2017).

\section{Null-cell adenomas}

Null-cell adenomas (NCAs) are defined by the lack of IHC staining of any anterior pituitary hormone or pituitary specific transcription factors (Mete \& Lopes 2017). They are now thought to present a very small proportion of all pitNETs (Sjostedt et al. 2017), and their true frequency is probably overestimated due to lack of examination of transcription factors, such as SF-1.

\section{Plurihormonal Pit-1 positive}

Pit-1 positive plurihormonal adenomas (previously named 'silent subtype 3 adenomas') are a distinct entity with more aggressive behaviour (Mete \& Lopes 2017). They demonstrate immunoreactivity for GH, PRL, and TSH in different combinations and, despite their 'silent' nature, approximately 30\% are associated with clinical signs of Pit-1 lineage hormone-hypersecretion leading to hyperthyroidism, acromegaly, or hyperprolactinemia, and are found more frequently in MEN1.

\section{Non-functioning pituitary carcinomas and aggressive pituitary tumours (APTs)}

PCs are defined by the presence of cerebrospinal and/or systemic distant metastasis and account for only $0.2 \%$ of pitNETs. APTs represent a small subtype characterised by local invasion of surrounding tissues, increased risk for multiple recurrences, rapid tumour growth, and/or resistance to treatment. The precise number of APTs remains unknown but may account for approximately $10 \%$ of all pitNETs in surgical series (Raverot et al. 2018).

\section{Clinical presentation}

The clinical presentation of NFpitNETs varies from completely asymptomatic to panhypopituitarism and manifestations attributed to mass effects to nearby structures. The lack of clinical symptoms related to hormonal hypersecretion is associated with a delay in diagnosis of approximately $1.96 \pm 2.9$ years
(Drange et al. 2000). In a recent large ( $>200$ participants), prospectively studied cohort of NFpitNETs, the presentation was approximately 50\% incidental and $50 \%$ due to tumour-related symptomatology (Freda et al. 2020). The prevalence of incidental presentation in this cohort, however, was somewhat higher than earlier reported in surgical series - where it ranged between $8.7 \%$ and $26.4 \%$ (Nomikos et al. 2004, Losa et al. 2008) - and in NFpitNETs cohorts that were followed conservatively where it ranged between 21\% and 37\% (Dekkers et al. 2007, Karavitaki et al. 2007).

Headache is the most common neurologic symptom observed in 19-75\% of patients (Rizzoli et al. 2016). Possible mechanisms related to headache include increased intrasellar pressure and stretching of the dural membrane or invasion of the cavernous sinus and trigeminal nerve irritation, but there are no specific features (Ntali \& Wass 2018).

Visual impairment is reported in $58 \%$ of patients (Cohen et al. 1985), mainly presenting as bitemporal hemianopia due to compression of the optic chiasm. However, visual field loss may be uni-, bilateral or central, as well as complete or partial, depending on the site and the degree of the nerve compression (Abouaf et al. 2015). In a recent study of 103 patients presenting to a neurosurgical unit with a pitNET, bitemporal visual field loss was the most common defect (41\%), but a significant proportion of patients also had unilateral or even altitudinal defects.

Ocular motor impairment associated with large pitNETs is attributed to cavernous sinus invasion and compression of cranial nerves III, IV and VI (Abouaf $e t$ al. 2015).

Hypopituitarism is also common in patients with NFpitNETs. GH deficiency is most commonly observed followed by gonadotrophins, ACTH and thyrotrophin insufficiency (Chen et al. 2011, Ntali \& Wass 2018). In addition, disconnection hyperprolactinaemia may be observed due to pituitary stalk compression and could account for some of the observed cases of hypogonadism (Karavitaki et al. 2006, Korevaar et al. 2012). Diabetes insipidus (DI) is an uncommon finding in cases of NFpitNETs and should direct investigation to another sellar pathology (Chen et al. 2011, Ntali \& Wass 2018).

Pituitary apoplexy in NFpitNETs is occasionally seen. In a retrospective study of 485 patients, pituitary apoplexy was the first presentation in $8 \%$ (Vargas et al. 2015). A systematic review and meta-analysis regarding the natural history of PIs and NFpitNETs reported an incidence of apoplexy in macroadenomas of $1.1 \%$ per year (FernandezBalsells et al. 2011). 

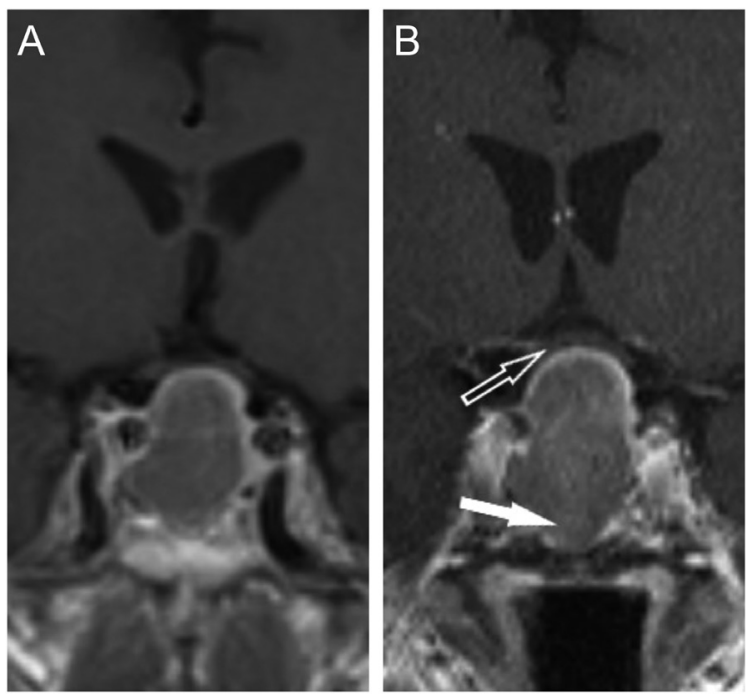

\section{Natural history}

The natural history of NFpitNETs has been studied in several, mainly retrospective, studies demonstrating a variety of biological behaviours. In most studies with long-term follow-up of un-operated NFpitNETs, initial tumour size was the main prognostic indicator of their biologic behaviour. Approximately $25-50 \%$ of patients with NF-macroadenomas demonstrate an increase in tumour size in follow-up periods of 22-73 months (Dekkers et al. 2007, Karavitaki et al. 2007) (Fig. 2). In a small cohort of un-operated NF-macroadenomas during a follow-up period of more than 7 years, tumour growth was observed in $50 \%$ of patients, $50 \%$ of whom also exhibited aggravation of a visual field defect and $25 \%$ an increase in hormone deficiencies (Table 2) (Dekkers et al. 2007). However, a spontaneous decrease in tumour volume was also reported in up to $30 \%$ in NF-macroadenomas (Table 2). NF-microadenomas grow less frequently compared to macroadenomas and the majority of them remain stable in size (Table 2), although an increase in tumour size in up to $50 \%$ of the NF-microadenomas in one cohort has also been reported (Sam et al. 2015).

The median annual growth rate differs significantly between macro- and micro-NFpitNETs; this is estimated at approximately $1.0 \mathrm{~mm} /$ year for macroadenomas and 0.4 $\mathrm{mm}$ /year for microadenomas (Sam et al. 2015), with the median time for the first radiological evidence of growth estimated at 1.4 years for macroadenomas and 1.5 years for microadenomas (Sam et al. 2015). Another significant factor appears to be the proximity of the adenoma to the optic chiasm; macroadenomas contacting the optic chiasm show a greater risk for tumour growth compared to those that do not (73\% vs 29\%) (Sam et al. 2015).

\section{Figure 2}

Coronal sections of contrast enhanced

T1-weighted MRIs of a 65-year-old female suffering from a NFpitNET. (A) Initial MRI showing a macroadenoma abutting the optic chiasm. (B) Follow-up MRI 3 years later showing enlargement of the tumour. Note the more pronounced compression of the optic chiasm (outlined white arrow) and the inferior extension towards the sphenoid sinus (solid white arrow). (C) Postoperative MRI showing satisfactory tumour removal and decompression of the optic chiasm (outlined white arrow). NFpitNETs, nonfunctioning pituitary neuroendocrine tumours; $\mathrm{MRI}$, magnetic resonance imaging.
The underlying molecular mechanisms that drive some tumours to grow remain currently unknown, and no specific prognostic markers of tumour growth have been identified. Furthermore, the risk of malignancy and aggressive biological behaviour in NFpitNETs varies widely according to the histological type and as to whether the tumours develop in the context of a genetic syndrome or are sporadic.

SCAs, sSAs, sTAs and silent plurihormonal PIT-1positive tumours are usually larger and exhibit more aggressive biological behaviour compared to other histologic subtypes (Trouillas et al. 2020), but the actual prognostic impact of these subtypes remains controversial. In addition, proliferative markers such as $\mathrm{Ki}-67 \mathrm{LI} \geq 3 \%$, mitotic count $>2$, and p53 expression (Raverot et al. 2017, Trouillas et al. 2013) are also considered of prognostic significance (Trouillas et al. 2020).

NFpitNETs are not the predominant type in patients with MEN1, but were previously proposed to display a more aggressive behaviour, similar to their functioning counterparts (Corbetta et al. 1997, Thakker et al. 2012), although this remains controversial. In the Dutch cohort of patients with MEN1, the majority of NFpitNETs were microadenomas and remained stable after a median follow-up of approximately 6 years, while none of them progressed to macroadenomas (de Laat et al. 2015). On the other hand, in the French and Belgian multicentre cohort of patients with MEN1, the frequency of symptomatic macroadenomas was significantly higher in MEN1 compared with non-MEN1 patients (Verges et al. 2002).

A recent large retrospective cohort study in UK investigated the growth rate of tumours in patients with NFpitNETs that showed tumour growth after surgery (Tampourlou et al. 2017). In this study the 5- and 10-year 
Table 2 The natural course of non-functioning pituitary neuroendocrine tumours.

\begin{tabular}{|c|c|c|c|c|c|}
\hline Authors & Study cohort & $\begin{array}{l}\text { Mean follow-up } \\
\text { (months) }\end{array}$ & $\begin{array}{l}\text { Increase in } \\
\text { tumour size (\%) }\end{array}$ & $\begin{array}{l}\text { Decrease in } \\
\text { tumour size (\%) }\end{array}$ & $\begin{array}{l}\text { Aggravation of visual } \\
\text { impairment }\end{array}$ \\
\hline Reincke et al. (1990) & $\begin{array}{l}n=14 \\
\text { (7 macroadenomas) }\end{array}$ & 22 & $\begin{array}{l}\text { Macro: } 29 \\
\text { Micro: } 14\end{array}$ & $\begin{array}{l}\text { Macro: } 0 \\
\text { Micro: } 7\end{array}$ & NR \\
\hline $\begin{array}{l}\text { Feldkamp et al. } \\
\text { (1999) }\end{array}$ & $\begin{array}{l}n=50 \\
\text { (19 macroadenomas) }\end{array}$ & 32 & $\begin{array}{l}\text { Macro: } 26.3 \\
\text { Micro: } 3.2\end{array}$ & $\begin{array}{l}\text { Macro: } 5.3 \\
\text { Micro: } 3.2\end{array}$ & NR \\
\hline $\begin{array}{l}\text { Donovan \& } \\
\text { Corenblum (1995) }\end{array}$ & $\begin{array}{l}n=31 \\
\text { (16 macroadenomas) }\end{array}$ & 73 & $\begin{array}{l}\text { Macro: } 25 \\
\text { Micro: } 0\end{array}$ & $\begin{array}{l}\text { Macro: } 0 \\
\text { Micro: } 0\end{array}$ & NR \\
\hline $\begin{array}{l}\text { Nishizawa et al. } \\
\text { (1998) }\end{array}$ & $\begin{array}{l}n=28 \\
\text { (macroadenomas) }\end{array}$ & 67.2 & 7 & - & NR \\
\hline Sanno et al. (2003) & $\begin{array}{l}n=115 \\
(\text { macro }+ \text { micro })\end{array}$ & 51 & 20 & 9 & NR \\
\hline Arita et al. (2006) & $\begin{array}{l}n=42 \\
\text { (37 macroadenomas) }\end{array}$ & 62 & $\begin{array}{l}\text { Macro: } 51 \\
\text { Micro: } 40\end{array}$ & - & NR \\
\hline $\begin{array}{l}\text { Dekkers et al. } \\
\text { (2007) }\end{array}$ & $n=28$ macroadenomas & 85 & 50 & 29 & $\begin{array}{l}50 \% \text { of the macroadenomas } \\
\text { with tumour growth }\end{array}$ \\
\hline $\begin{array}{l}\text { Karavitaki et al. } \\
\text { (2007) }\end{array}$ & $\begin{array}{l}n=40 \\
\text { (24 macroadenomas) }\end{array}$ & 42 & $\begin{array}{l}\text { Macro: } 50 \\
\text { Micro: } 12.5\end{array}$ & $\begin{array}{l}\text { Macro: } 16.7 \\
\text { Micro: } 6.3\end{array}$ & $\begin{array}{l}67 \% \text { of the macroadenomas } \\
\text { with tumour growth }\end{array}$ \\
\hline Sam et al. (2015) & $\begin{array}{l}n=66 \\
\text { (47 macroadenomas) }\end{array}$ & 51.6 & $\begin{array}{l}\text { Macro: } 59.6 \\
\text { Micro: } 52.6\end{array}$ & $\begin{array}{l}\text { Macro: } 34 \\
\text { Micro: } 31.6\end{array}$ & $19 \%$ of the macroadenomas \\
\hline Iglesias et al. (2017) & $\begin{array}{l}n=23 \\
(\text { macro + micro })\end{array}$ & 15.5 & 3.8 & 7.7 & NR \\
\hline
\end{tabular}

Clinical studies on the long term follow up of non-functioning pituitary neuroendocrine tumours. Macro, macroadenomas; micro, microadenomas; NR, not reported.

second regrowth rates were 35.3 and $46.7 \%$, respectively, highlighting the need for long-term follow up in this patient population. In addition, a relatively high rate of patients, approximately $16 \%$, with no visible tumour after surgery, showed the first regrowth at a follow-up period of 50 months, in line with previous studies (Greenman et al. 2003). Second surgery with or without adjuvant RT demonstrated favourable outcomes in avoiding further enlargement of the tumour compared to monitoring alone, indicating the need for active therapeutic intervention when appropriate (Tampourlou et al. 2017). In addition, a recent study observed that MRI texture analysis on T1-weighted images could predict the risk of tumour recurrence or progression after surgery, and this clearly requires further study (Galm et al. 2018).

Long-term mortality in these patients also appears to be higher than that of the general population (Pagesy et al. 1991, Tomlinson et al. 2001, Nielsen et al. 2007, Olsson et al. 2015, Ntali et al. 2016), although an improvement has been reported in the last decade, highlighting the efficacy of recent advances in the diagnosis and treatment of PitNETs. Cardiocerebrovascular events, infections, and malignancies appear to be the most common causes of death in NFpitNETs patients with long-term follow-up (Ntali et al. 2016). However, when such patients are treated and adequately replaced, their quality of life does not appear to be different to the normal population (Capatina et al. 2013, Karppinen et al. 2016). Changes in tumour phenotype have also been reported in some subtypes of NFpitNETs, although the underlying molecular mechanisms remain unknown. A large single-centre retrospective cohort of surgically resected NFpitNETs $(n=124)$ over 10 years reported that $11 \%$ of sSAs and $5.6 \%$ of sCAs converted to functional adenomas during follow-up (Langlois et al. 2017). In another study, 3.9\% of sCAs switched to Cushing's disease in a transformation time of 1-7 years (Righi et al. 2017). Thus, close monitoring of such NFpitNETs is recommended not only because of their high risk of recurrence but also due to the risk of becoming functional over time.

\section{The role of molecular biology in the pathogenesis and biological behaviour of NFpitNETs}

Recent advances in molecular genetics have identified both somatic and germline mutations, associated with familial syndromes, in apparent sporadic cases of NFpitNETs (Vandeva et al. 2019).

Of the genes that have been implicated in the pathophysiology of pitNETs, guanine nucleotide-binding protein, alpha stimulating (GNAS), aryl hydrocarbon
C) 2020 Society for Endocrinology Published by Bioscientifica Ltd. Printed in Great Britain 
receptor interacting protein $(A I P)$, and pituitary tumour transforming gene (PTTG) have been more frequently described in NFpitNETs (Jiang \& Zhang 2013, Aflorei \& Korbonits 2014).

Of sporadic NFpitNETs, germline MEN1 mutations (MEN type 1) are rare (>3\%) and CDKN1B mutations (MEN type 4) have not been reported thus far, whereas the role of PRKAR1A somatic mutations (Carney complex) in the development of sporadic functioning and NFPitNETs remains unknown (Kaltsas et al. 2002). Activating somatic mutations of the PIK3CA gene that encodes for the catalytic subunit of PI3-Kinase IA have also been described in NFpitNETs (Vandeva et al. 2019).

In the recent study with multi-genomic characterisation of PitNETs, the cohort of 134 tumours included 21 silent pitNETs (sCAs, sGAs, and NCAs) where no functional somatic variant or chromosome alteration was identified (Neou et al. 2020).

Other genes, encoding for proteins related to cytoskeleton and intracellular signallings, have demonstrated promising results in predicting the risk of invasiveness in NFpitNETs. Tumour growth factorbeta (TGF- $\beta$ )/Smad signalling is involved in a number of cellular processes such as proliferation, differentiation, and apoptosis. Expression of TGF- $\beta$ receptor type 2 at both mRNA and protein level and phosphorylated Smad3 protein were inversely correlated with tumour invasiveness in NFpitNETs (Zhenye et al. 2014, Gu \& Feng 2018). In addition, tissue expression of the Ezrin (EZR) gene, a cell membrane component that links the cytoskeleton with the cell membrane, in NCAs and sGAs, was directly correlated with increased invasiveness in these tumours: in vitro silencing of the EZR gene in human pituitary adenoma cell line GH3 inhibited tumour growth (Chen et al. 2017), indicating that tissue expression of EZR can serve both as a prognostic biomarker of aggressiveness and as a novel molecular therapeutic target to control tumour growth.

Epigenetically, the DNA methylation profile of PitNETs differs between functioning and NFpitNETs, at least in some subtypes. In a genome-wide analysis, somatotrophinomas displayed higher levels of hypomethylated DNA regions compared to functioning corticotroph adenomas and sGAs (Salomon et al. 2018). In addition, sGAs displayed a high proportion of hypermethylated DNA regions while sCAs high proportion of hypomethylated DNA regions (Salomon et al. 2018). Data remain inconclusive regarding the prognostic effect of DNA methylation on the biologic behaviour of NFpitNETs.

In contrast to the other epigenetic mechanisms that modulate gene transcription, non-coding RNAs, including long-non-coding RNAs (lncRNAs), short miRNA and circular RNAs (circRNAs), control gene expression at the post-transcriptional level and are associated with the pathogenesis of various diseases including cancer. miRs are small single-stranded RNA molecules of 22 nucleotides that modulate the gene expression of mRNA genes. In a recent study, the expression of specific miRs, namely miR-26b-5p, miR-30a-5p, and miR-508-5p, was significantly and inversely correlated with histological and clinical parameters of tumour aggressiveness (Vicchio et al. 2020). In addition, two circRNAs that were identified in tissue samples of NFpitNETs, circRNA-0000066 and circRNA0-0069707, were significantly associated with tumour recurrence post-surgery (Guo et al. 2019): they may act synergistically to modulate the response of transport vesicles and cells to unfolded proteins at the cellular and tissue level (Guo et al. 2019). IncRNAs are transcripts of more than 200 nucleotides and act as 'sponges' for miRs and a guide for chromatin modifiers. Certain lncRNAs, namely HOX transcript antisense RNA (HOTAIR), maternally expressed 3 (MEG3) and metastasisassociated lung adenocarcinoma transcript 1 (MALAT-1) appear to associate with the development and biological behaviour of NFpitNETs (Li et al. 2017).

However, as of now, molecular studies on NFpitNETs have not essentially been able to predict which tumours could be managed conservatively vs surgically, a major requirement for clinicians.

\section{Management}

\section{Active surveillance}

Although few data are available regarding the treatment of asymptomatic and incidentally discovered NFpitNETs, there is a trend towards a conservative approach. However, there is no established follow-up algorithm and guidelines are typically based on clinical experience (Freda et al. 2011, Chanson et al. 2015). All patients with a PI or a clinically apparent NFpitNET should undergo complete evaluation of anterior pituitary function, as in many cases hormone hypersecretion or hypopituitarism may be subtle and slowly progressive (Freda et al. 2011, Chanson et al. 2015, Ntali \& Wass 2018) (Table 3). Formal visual field assessment may also be reassuring in some cases. In the case of a macroadenoma, it is also recommended to undertake clinical and biochemical assessment of anterior pituitary function for the development of hypopituitarism 6 months after diagnosis and at least annually afterwards. (c) 2020 Society for Endocrinology Published by Bioscientifica Ltd. Printed in Great Britain 
Table 3 Initial endocrine evaluation of non-functioning pituitary neuroendocrine tumours.

Evaluation for hormone hypersecretion

- Measure serum IGF-1.

- Measure serum prolactin (in dilution in case of large macroadenomas).Screening for glucocorticoid excess in case of clinical suspicion (overnight dexamethasone suppression test, late-night salivary cortisol).

Evaluation for hypopituitarism

- Measure serum cortisol (09:00 h), TSH, fT4, IGF-1, prolactin, $\mathrm{FSH}$, LH, testosterone (males), oestradiol (females).

- A morning cortisol level $<100 \mathrm{nmol} / \mathrm{L}$ is suggestive of adrenal insufficiency while a cortisol level $>430 \mathrm{nmol} / \mathrm{L}$ excludes the diagnosis (note, however, these values may vary dependent on assay). If the cortisol level is between 100 $\mathrm{nmol} / \mathrm{L}$ and $430 \mathrm{nmol} / \mathrm{L}$, a corticotropin stimulation test should be performed.In case GH deficiency is suspected, GH stimulation tests should be performed to exclude or confirm the diagnosis.Gonadal function in premenopausal women is assessed through history and examination. Low gonadotrophin levels in post-menopausal women suggest hypopituitarism. In men, need to exclude primary hypogonadism if testosterone levels are low, but may need to take into account SHBG and hence free testosterone.

A baseline hormonal evaluation and assessment of potential hypopituitarism is strongly suggested for all non-functioning pituitary neuroendocrine tumours.

Routine follow-up for hypopituitarism is not suggested for microadenomas whose clinical picture and MRI rarely change over time (Freda et al. 2011, Chanson et al. 2015) (Fig. 3).

It is recommended that microadenomas are followed-up at 6 months with MRI and then every 1-2 years until there has been absence of progression over 2 years. No surveillance is routinely recommended for microadenomas with a diameter $<5 \mathrm{~mm}$ (Chanson et al. 2015). In the case of a macroadenoma that is not close to the optic chiasm, follow-up with MRI 1 year after initial diagnosis is performed; if no progression is observed, surveillance is recommended every 1-2 years. Formal visual field assessment is suggested if the tumour enlarges to abut or compress the optic chiasm during follow-up. In the instance of a macroadenoma close to the optic chiasm, MRI should be performed at 6 months and at least annually thereafter or when symptoms arise. Visual assessment may be performed every 6 months (Chanson et al. 2015).

\section{Surgical treatment}

Surgical treatment of NFpitNETs is performed in patients with visual or neurological abnormalities, in tumours that display significant growth, cause loss of endocrine function, or are close to the optic chiasm, in patients with persistent headache, or in women planning to become pregnant (Freda et al. 2011, Chanson et al. 2015). Active surveillance may be a better approach for older patients as they display a higher surgical intervention risk, while also having a shorter lifetime probability of tumour enlargement. Currently, the standard surgical technique is endoscopic- or microscopic-assisted transsphenoidal surgery (TSS). A recent meta-analysis showed that endoscopic surgery was associated with higher gross tumour removal and lower risk of septal perforation compared with the microscopic approach (Li et al. 2017). Intra-operative MRI has been recently introduced as a means to improve the surgical resection of the tumour, but its use remains controversial as it is unclear as to whether the extra time and expense are worth the technique, other than in exceptional cases (Tandon et al. 2017).

TSS, when performed by an experienced surgeon, is a safe procedure with relatively low complication rates: a total resection is achieved in $60-73 \%$ of NFPitNETs (Yu et al. 2018). Immediate tumour volume decrease was observed in nearly all patients with a residual tumour rate of 10-36\% (Lucas et al. 2016). Visual improvement is observed in $75-91 \%$ of patients, while $35-50 \%$ of patients display an improvement in hypopituitarism (Lucas et al. 2016). It has been reported that a postoperative improvement in gonadal, thyroid and adrenal axes occurs in $64.9,71.9$ and $33.9 \%$ of cases, respectively (Nomikos et al. 2004). Post-operative complications occur in less than $5 \%$ of patients, while the mortality rate is low $(<1 \%)$ in expert hands (Murad et al. 2010, Casanueva et al. 2017). New anterior pituitary deficits developed in $9 \%$ of patients in one series, while deterioration of central hypoadrenalism, hypothyroidism and hypogonadism was reported in 39, 17 and $10 \%$ of cases, respectively (Murad et al. 2010). DI occurs in 18-31\% of patients after pituitary surgery but in most cases is transient and attributed to the temporary dysfunction of vasopressin/ ADH-secreting neurons (Esposito et al. 2019).

Assessment of pituitary function and visual field examination should be performed 1-3 months postoperatively and hormone deficiencies reassessed and treated, as appropriate. A sellar MRI should be performed 3-6 months post-operatively to estimate tumour resection and to serve as baseline MRI during subsequent follow-up. In the case of no residual tumour on imaging, the 10-year regrowth rate ranged between $<6 \%$ (Reddy et al. 2011) and 16\% (Tampourlou et al. 2017), while with residual tumour the regrowth rate increases reaching 42 to $53 \%$ or 77 to $80 \%$ dependent on whether the residual is intrasellar or extrasellar, respectively (O'Sullivan et al. 2009, Reddy et al. 2011). 


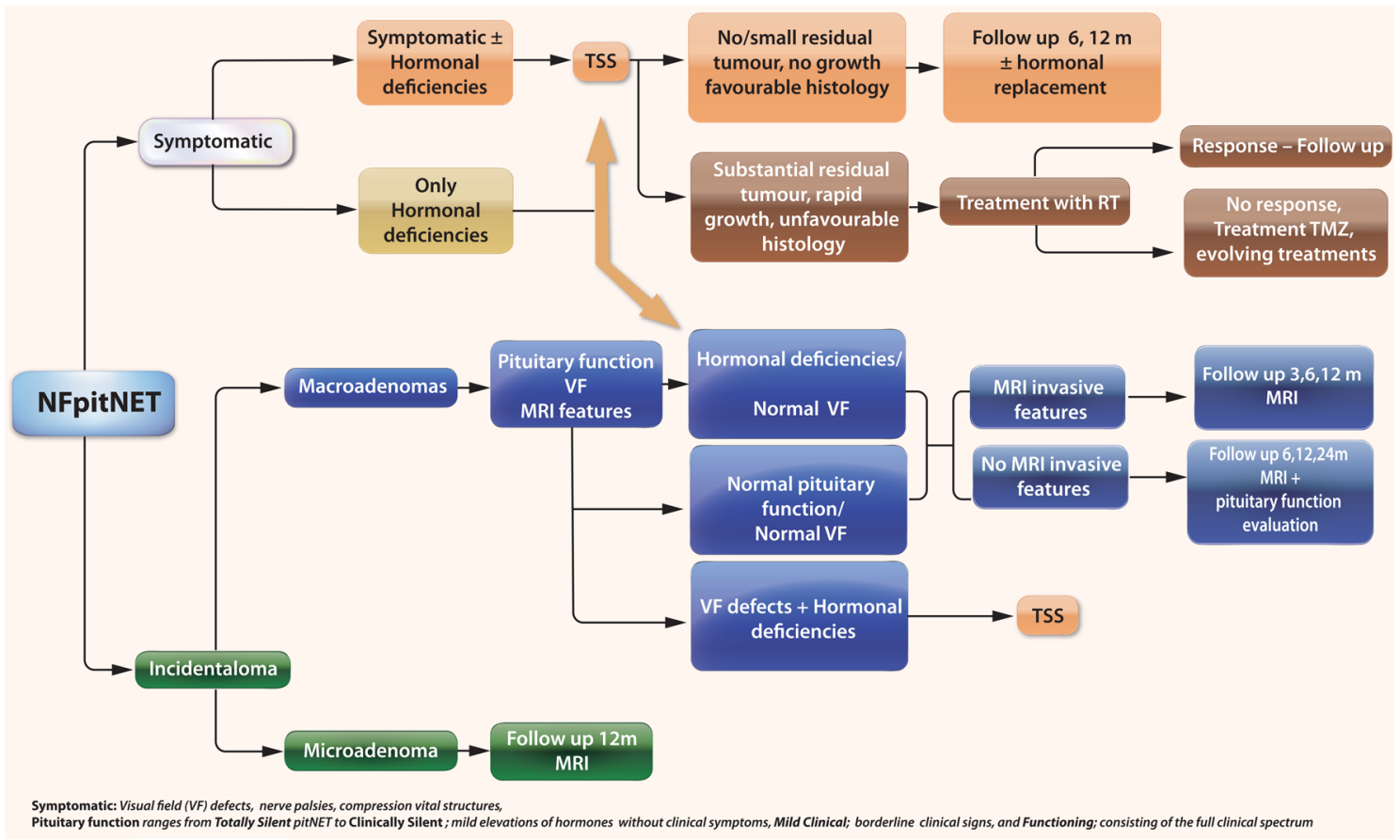

Figure 3

Management of NFpitNETs algorithm. NFpitNETs, non-functioning pituitary neuroendocrine tumours; VF, visual defects; TSS, transsphenoidal surgery; $\mathrm{RT}$, radiotherapy; $\mathrm{TMZ}$, temozolomide.

\section{Management of recurrent tumours}

Apparent complete resection of NFpitNETs after initial surgery is achieved in 69 and $64.5 \%$ of patients in case of endoscopic or microscopic approach, respectively (Ammirati et al. 2013). However, as noted previously, tumour relapse has been reported in approximately $7-12 \%$ of cases at 10 years, while growth of residual disease is frequently observed in case of incomplete resection (O'Sullivan et al. 2009, Reddy et al. 2011, Chen et al. 2012).

In the past, RT was administered post-operatively in some centres to all patients to prevent recurrence or growth of residual tumour. However, today the role of RT as adjuvant treatment is under debate. 'Conventional radiotherapy' has been replaced by much more precise techniques, intensity-modulated fractionated stereotactic radiotherapy and gamma-knife radiosurgery, which aim to deliver high precision radiotherapy with lower complication rates (Minniti et al. 2016).

Several studies have evaluated the efficacy of adjuvant RT on tumour growth or recurrence. A recent study has reported $85-95 \%$ of tumour control at 5-10 years postoperatively in patients with NFpitNETs (Minniti et al. 2016). Mean progression free survival (PFS) at 5 years post-operatively was 95\% after RT compared to $70 \%$ in patients not treated with RT. At 15 years post-operatively, mean PFS was calculated as 93\% after RT compared to 33\% if no RT was administered (Gittoes et al. 1998). However, there are no randomised controlled trials indicating the superiority of adjuvant post-operative RT compared to active surveillance, while the potential side-effects of RT render the indication for RT debatable (Chanson et al. 2019). Furthermore, a recent meta-analysis reported that residual tumour growth occurs slowly as the tumour doubling time is only 3.4 years with no growth observed during follow-up in 50-60\% of patients (Chen et al. 2012). There is thus no consensus regarding adjuvant treatment with RT after surgical resection of NFpitNETs. Certainly, unless the tumour exhibits especial aggressiveness radiologically and/or histopathologically, we believe RT should be reserved for the time of disease progression during follow-up, while immediate post-operative treatment should be reserved for cases with significant tumour remnant and high risk of progression (Lucas et al. 2016). Furthermore, adjuvant RT should be considered for patients presenting with aggressive NFpitNENs, large tumours with suprasellar extension or cavernous sinus invasion or displaying aggressive histopathological characteristics such as a LI Ki-67 $>3 \%$ or extensive immunostaining for p53 (Chanson et al. 2019). RT may also be used as primary treatment in cases where surgery is not feasible. 
The most common side effect of RT is the high incidence of hypopituitarism. Five years after treatment with RT, the incidence of GH, gonadotrophin, ACTH and TSH deficiency has been calculated to 100, 91, 77 and 42, respectively (Littley et al. 1989). Follow-up with assessment of anterior pituitary function is recommended every 6 months post-treatment with RT. Rare side effects of RT include optic neuropathy, neurocognitive dysfunction, a probably increased risk of secondary malignancies of the CNS, and an increased risk of cerebrovascular events (Brada et al. 1993, Chanson et al. 2019). Visual problems are exceptionally rare for fractionated RT as long as the daily dose is $<1.80 \mathrm{~Gy}$ and the total dose does not exceed $45 \mathrm{~Gy}$, and for single-dose radiosurgery, the dose to the optic apparatus is $<8 \mathrm{~Gy}$, although it may still occur.

There are currently few data regarding revision TSS in case of recurrent NFpitNETs. Overall, the results are less favourable after revision surgery compared to the primary procedure. It has been reported that gross total resection is achieved in $46-53.5 \%$ of cases after revision surgery compared to $69-71 \%$ after primary surgery (Esquenazi et al. 2017). A recent study comparing the outcomes of primary and revision TSS observed no significant difference in the length of hospital stay and the post-operative hypopituitarism or hyponatraemia, but reported higher rates of DI and CSF leak after revision compared to primary cases (Jahangiri et al. 2014). Hence, revision surgery is indicated in the case of progressive residual tumour that can be completely resected, in symptomatic compression of the optic chiasm, and in cases of progression after treatment with RT (Chanson et al. 2015).

\section{Medical treatment}

As incomplete resection of NFpitNETs is a common clinical outcome, the development of effective medical treatment would be of great value. Based on observations that NFpitNETs express dopamine receptors (DR) and SSTRs (particularly DR2, SSTR2 and SSTR5), several studies have evaluated the efficacy of dopamine agonists (DAs) and somatostatin analogues (SSAs) in patients with operated or un-operated NFpitNETs (Colao et al. 2008, Greenman et al. 2016). Earlier studies showed no effect of bromocriptine (Grossman et al. 1985). However, in a recent cohort of 79 patients with post-operative residual tumour treated with bromocriptine $(2.5-10 \mathrm{mg}$ qd) or cabergoline (0.5-3.5 mg weekly), either upon imaging detection of residual tumour or after tumour growth, a positive effect was observed. In the first group, tumour control (shrinkage or stabilisation) was observed in $87 \%$ of patients, while in the latter tumour stabilisation or shrinkage was achieved in 58 and $29 \%$, respectively (Greenman et al. 2016). A recent randomised clinical trial that compared cabergoline (3.5 mg weekly) with nonintervention in patients with residual adenoma after TSS found that cabergoline was associated with a high rate of tumour shrinkage (28.8\%), while tumour stabilisation was observed in $66.1 \%$ of patients (Batista et al. 2019). There is limited clinical experience regarding the use of SSAs in NFpitNETs (Colao et al. 2008). A case-control study evaluated the efficacy of long-acting SSA octreotide LAR in patients with residual tumours that displayed positive SSTR scintigraphy (Fusco et al. 2012). Tumour stabilisation was observed in $81 \%$ of patients that received treatment compared with $47 \%$ in the control group during a mean follow-up time of 37 months. However, neither tumour shrinkage nor visual field changes, and no pituitary function improvement, were observed in any patient after treatment with SSAs. There are no clinical studies evaluating the treatment with pasireotide in patients with NFpitNETs, while in vitro studies have shown conflicting results (Ibanez-Costa et al. 2016).

Recently, newly synthesised chimeric somatostatin/ dopamine compounds ('dopastatins') have shown some efficacy in the management of pitNETs in in vitro and in vivo studies. The chimeric molecule BIM-23A760 inhibited in vitro cell proliferation in two-thirds of NFpitNETs. Chronic administration of BIM-23A760, however, produced a metabolite with dopaminergic activity that interfered with the activity of the initial compound (Culler 2011). The new generation chimeric agonist for SSTR2/SSTR5/DR2, BIM-065, designed with a different chemical structure to avoid the accumulation of metabolites with loss of dopaminergic activity, also increased apoptosis in NFpitNETs cell cultures (Vázquez-Borrego et al. 2020). A chimeric compound with potent agonist activity both at D2R and SSTR2, TBR-760, was tested in vivo in a mouse model of an aggressive NFpitNET, the proopiomelanocortin gene knockout (POMC-KO) mouse that expresses D2R and SSTR2 at a similar level to human NFpitNETs. TBR-760 completely suppressed tumour growth in this mouse-model, despite the highly aggressive nature of the POMC-KO tumours (Halem et al. 2020).

In addition, there are some reports of symptomatic improvement and tumour control achieved in patients with atypical adenomas treated with peptide receptor radionuclide therapy (PRRT) (Komor et al. 2014). However, prospective clinical trials are required to establish the efficacy and safety of this therapeutic option. 


\section{Management of aggressive tumours}

The management of APTs is difficult due to their large size, rapid growth, invasiveness and increased rate of recurrence. Therapeutic options include surgery, RT, medical treatment and PRRT, best managed by a multidisciplinary expert team (Casanueva et al. 2017, Raverot et al. 2018). Temozolomide is an alkylating agent currently approved for the treatment of brain gliomas and glioblastomas. Recently, the European Society of Endocrinology (ESE) recommended the use of TMZ as first-line treatment for APTs and PCs either as monotherapy or in combination with radiotherapy in patients with rapid tumour growth that have not received the maximal radiotherapy dose (Raverot et al. 2018). In a recently published series of patients with APTs or PCs treated with TMZ as first-line chemotherapy, a radiological response was observed in $37 \%$ of the patients, disease stability in 33\% and progression in $30 \%$. The peak radiological response was observed within 3 and 6 months in 23 and 59\% of cases, respectively (McCormack et al. 2018). However, tumour recurrence is common after cessation of treatment and 2-year PFS has been calculated to be $47.7 \%$ (Losa et al. 2016). In addition, it has been observed that NFPitNETs display lower response rates to temozolomide compared to functioning tumours (Raverot et al. 2018). The DNA repair enzyme O6-methylguanine-DNA methyltransferase (MGMT) that reverses the methylation caused by TMZ represents the major mechanism of resistance on treatment with TMZ, but the absence of MGMT expression could not always predict the tumour response to treatment (Chatzellis et al. 2015). The ESE has recommended an initial trial of three cycles of TMZ and subsequent radiological assessment of disease response. Cessation of treatment is suggested if radiological progression is observed (Raverot et al. 2018).

Raf/MEK/ERK and PI3K/Akt/mTOR pathways are upregulated in pitNETs (Dworakowska \& Grossman 2009). As a result, several studies suggest that newly targeted agents may be effective in controlling PitNET growth (Raverot et al. 2018, Ilie et al. 2019). Everolimus, an mTOR inhibitor, was tested in APTs and PCs, but was found to be unsuccessful in most cases (Ilie et al. 2019). Preclinical trials have observed that the efficacy of everolimus may be enhanced when administered in combination with SSAs (Zatelli et al. 2010). There is some evidence suggesting the use of tyrosine kinase inhibitors in the treatment of APTs. Lapatinib, erlotinib and sunitinib have been used as firstor second-line treatment, but tumour progression was demonstrated in most cases (Raverot et al. 2018 Ilie et al. 2019). Combination treatment of TMZ and apatinib was successful in a patient with recurrent invasive GH-secreting adenoma for 31.5 months without recurrence (Wang et al. 2019). In addition, vascular endothelial growth factor (VEGF)-targeted therapy (bevacizumab) has been administered, either as monotherapy or in combination with TMZ, with promising results (Ilie et al. 2019). However, few patients have been treated so far and further investigation is required to introduce the use of targeted agents in the treatment of APTs.

There is also limited experience with PRRT in APTs, and tumour shrinkage or disease stability has been observed in some cases. However, disease progression was observed in some patients during treatment or shortly after the cessation of treatment. As PRRT seems a promising treatment option, recent in vivo and in vitro studies aim to investigate the possibility of upregulating the expression of SSTR2 in order to increase the efficacy of PRRT (Taelman et al. 2016).

Combination of two immune checkpoint inhibitors, nivolumab and ipilimumab, was effective in the management of a case with a corticotroph carcinoma (Lin et al. 2018). A clinical trial (NCT02834013) is also ongoing investigating the efficacy of this combination in PCs.

\section{Conclusions}

NFpitNENs comprise a heterogeneous group of tumours that usually follow an indolent course, although in some cases they may display aggressive behaviour characterised by rapid growth, early recurrence and resistance to conventional treatment. Identification of clinical and/ or histological characteristics, and molecular-based biomarkers that can accurately predict aggressiveness of these tumours, is currently under intense investigation. The most recent data suggest that a conservative approach may often be most appropriate, as even if surgery is offered there is still a high chance of recurrence, especially if scanning shows residual tumour. Medical therapy looks promising but is in its infancy, although cabergoline or possibly dopastatins will play increasing roles. Highly aggressive tumours will need particular care, including the use of TMZ and newer agents. What is clear is that we need molecular markers able to predict future behaviour, and these are still unavailable. Perhaps the next decade will more clearly establish a role for such markers and improve our prognostic capacity. For the moment, active surveillance remains a key part of the therapeutic strategy. (c) 2020 Society for Endocrinology Published by Bioscientifica Ltd. Printed in Great Britain 


\section{Declaration of interest}

The authors declare that there is no conflict of interest that could be perceived as prejudicing the impartiality of this review.

\section{Funding}

This work did not receive any specific grant from any funding agency in the public, commercial or not-for-profit sector.

\section{Acknowledgement}

The authors are very grateful to Dr Ozgur Mete for the provision of Table 1.

\section{References}

Abouaf L, Vighetto A \& Lebas M 2015 Neuro-ophthalmologic exploration in non-functioning pituitary adenoma. Annales d'Endocrinologie $\mathbf{7 6}$ 210-219. (https://doi.org/10.1016/j.ando.2015.04.006)

Aflorei ED \& Korbonits M 2014 Epidemiology and etiopathogenesis of pituitary adenomas. Journal of Neuro-Oncology 117 379-394. (https:// doi.org/10.1007/s11060-013-1354-5)

Agustsson TT, Baldvinsdottir T, Jonasson JG, Olafsdottir E, Steinthorsdottir V, Sigurdsson G, Thorsson AV, Carroll PV, Korbonits M \& Benediktsson R 2015 The epidemiology of pituitary adenomas in Iceland, 1955-2012: a nationwide population-based study. European Journal of Endocrinology 173 655-664. (https://doi. org/10.1530/EJE-15-0189)

Al-Dahmani K, Mohammad S, Imran F, Theriault C, Doucette S, Zwicker D, Yip CE, Clarke DB \& Imran SA 2016 Sellar masses: an epidemiological study. Canadian Journal of Neurological Sciences $\mathbf{4 3}$ 291-297. (https://doi.org/10.1017/cjn.2015.301)

Alrezk R, Hannah-Shmouni F \& Stratakis CA 2017 MEN4 and CDKN1B mutations: the latest of the MEN syndromes. Endocrine-Related Cancer 24 T195-T208. (https://doi.org/10.1530/ERC-17-0243)

Ammirati M, Wei L \& Ciric I 2013 Short-term outcome of endoscopic versus microscopic pituitary adenoma surgery: a systematic review and meta-analysis. Journal of Neurology, Neurosurgery, and Psychiatry 84 843-849. (https://doi.org/10.1136/jnnp-2012-303194)

Arita K, Tominaga A, Sugiyama K, Eguchi K, Iida K, Sumida M, Migita K \& Kurisu K 2006 Natural course of incidentally found nonfunctioning pituitary adenoma, with special reference to pituitary apoplexy during follow-up examination. Journal of Neurosurgery 104 884-891. (https://doi.org/10.3171/ jns.2006.104.6.884)

Asa SL, Casar-Borota O, Chanson P, Delgrange E, Earls P, Ezzat S, Grossman A, Ikeda H, Inoshita N, Karavitaki N, et al. 2017 From pituitary adenoma to pituitary neuroendocrine tumor (PitNET): an International Pituitary Pathology Club proposal. Endocrine-Related Cancer 24 C5-C8. (https://doi.org/10.1530/ERC-17-0004)

Batista RL, Musolino NRC, Cescato VAS, da Silva GO, Medeiros RSS, Herkenhoff CGB, Trarbach EB \& Cunha-Neto MB 2019 Cabergoline in the management of residual nonfunctioning pituitary adenoma: a single-center, open-label, 2-year randomized clinical trial. American Journal of Clinical Oncology 42 221-227. (https://doi.org/10.1097/ COC.0000000000000505)

Brada M, Rajan B, Traish D, Ashley S, Holmes-Sellors PJ, Nussey S \& Uttley D 1993 The long-term efficacy of conservative surgery and radiotherapy in the control of pituitary adenomas. Clinical Endocrinology 38 571-578. (https://doi.org/10.1111/j.1365-2265.1993. tb02137.x)
Capatina C, Christodoulides C, Fernandez A, Cudlip S, Grossman AB, Wass JA \& Karavitaki N 2013 Current treatment protocols can offer a normal or near-normal quality of life in the majority of patients with non-functioning pituitary adenomas. Clinical Endocrinology $\mathbf{7 8}$ 86-93. (https://doi.org/10.1111/j.1365-2265.2012.04449.x)

Casanueva FF, Barkan AL, Buchfelder M, Klibanski A, Laws ER, Loeffler JS, Melmed S, Mortini P, Wass J, Giustina A, et al. 2017 Criteria for the definition of pituitary tumor centers of excellence (PTCOE): a pituitary society statement. Pituitary 20 489-498. (https://doi.org/10.1007/s11102-017-0838-2)

Chanson P, Raverot G, Castinetti F, Cortet-Rudelli C, Galland F, Salenave S \& French Endocrinology Society non-functioning pituitary adenoma work-group 2015 Management of clinically nonfunctioning pituitary adenoma. Annales d'Endocrinologie 76 239-247. (https://doi.org/10.1016/j.ando.2015.04.002)

Chanson P, Dormoy A \& Dekkers OM 2019 Use of radiotherapy after pituitary surgery for non-functioning pituitary adenomas. European Journal of Endocrinology 181 D1-D13. (https://doi.org/10.1530/EJE-190058)

Chatzellis E, Alexandraki KI, Androulakis II \& Kaltsas G 2015 Aggressive pituitary tumors. Neuroendocrinology 101 87-104. (https://doi. org/10.1159/000371806)

Chen L, White WL, Spetzler RF \& Xu B 2011 A prospective study of nonfunctioning pituitary adenomas: presentation, management, and clinical outcome. Journal of Neuro-Oncology 102 129-138. (https:// doi.org/10.1007/s11060-010-0302-x)

Chen Y, Wang CD, Su ZP, Chen YX, Cai L, Zhuge QC \& Wu ZB 2012 Natural history of postoperative nonfunctioning pituitary adenomas: a systematic review and meta-analysis. Neuroendocrinology 96 333-342. (https://doi.org/10.1159/000339823)

Chen Y, Chuan HL, Yu SY, Li CZ, Wu ZB, Li GL \& Zhang YZ 2017 A novel invasive-related biomarker in three subtypes of nonfunctioning pituitary adenomas. World Neurosurgery 100 514-521. (https://doi.org/10.1016/j.wneu.2017.01.010)

Cohen AR, Cooper PR, Kupersmith MJ, Flamm ES \& Ransohoff J 1985 Visual recovery after transsphenoidal removal of pituitary adenomas. Neurosurgery 17 446-452. (https://doi.org/10.1227/00006123198509000-00008)

Colao A, Di Somma C, Pivonello R, Faggiano A, Lombardi G \& Savastano S 2008 Medical therapy for clinically non-functioning pituitary adenomas. Endocrine-Related Cancer 15 905-915. (https:// doi.org/10.1677/ERC-08-0181)

Corbetta S, Pizzocaro A, Peracchi M, Beck-Peccoz P, Faglia G \& Spada A 1997 Multiple endocrine neoplasia type 1 in patients with recognized pituitary tumours of different types. Clinical Endocrinology 47 507-512. (https://doi. $\operatorname{org} / 10.1046 / \mathrm{j} .1365-2265.1997 .3311122 . x)$

Correa R, Salpea P \& Stratakis CA 2015 Carney complex: an update. European Journal of Endocrinology 173 M85-M97. (https://doi. org/10.1530/EJE-15-0209)

Culler MD 2011 Somatostatin-dopamine chimeras: a novel approach to treatment of neuroendocrine tumors. Hormone and Metabolic Research 43 854-857. (https://doi.org/10.1055/s-0031-1287769)

Daly AF, Jaffrain-Rea ML, Ciccarelli A, Valdes-Socin H, Rohmer V, Tamburrano G, Borson-Chazot C, Estour B, Ciccarelli E, Brue T, et al. 2006 Clinical characterization of familial isolated pituitary adenomas. Journal of Clinical Endocrinology and Metabolism 91 3316-3323. (https://doi.org/10.1210/jc.2005-2671)

de Laat JM, Dekkers OM, Pieterman CR, Kluijfhout WP, Hermus AR, Pereira AM, van der Horst-Schrivers AN, Drent ML, Bisschop PH, Havekes B, et al. 2015 Long-term natural course of pituitary tumors in patients with MEN1: results from the DutchMEN1 Study Group (DMSG). Journal of Clinical Endocrinology and Metabolism 100 3288-3296. (https://doi.org/10.1210/JC.2015-2015)

Dekkers OM, Hammer S, de Keizer RJ, Roelfsema F, Schutte PJ, Smit JW, Romijn JA \& Pereira AM 2007 The natural course of non-functioning 
pituitary macroadenomas. European Journal of Endocrinology 156 217-224. (https://doi.org/10.1530/eje.1.02334)

Donovan LE \& Corenblum B 1995 The natural history of the pituitary incidentaloma. Archives of Internal Medicine 155 181-183.

Drange MR, Fram NR, Herman-Bonert V \& Melmed S 2000 Pituitary tumor registry: a novel clinical resource. Journal of Clinical Endocrinology and Metabolism 85 168-174. (https://doi.org/10.1210/ jcem.85.1.6309)

Drummond J, Roncaroli F, Grossman AB \& Korbonits M 2019 Clinical and pathological aspects of silent pituitary adenomas. Journal of Clinical Endocrinology and Metabolism 104 2473-2489. (https://doi. org/10.1210/jc.2018-00688)

Dwight T, Mann K, Benn DE, Robinson BG, McKelvie P, Gill AJ, Winship I \& Clifton-Bligh RJ 2013 Familial SDHA mutation associated with pituitary adenoma and pheochromocytoma/ paraganglioma. Journal of Clinical Endocrinology and Metabolism 98 E1103-E1108. (https://doi.org/10.1210/jc.2013-1400)

Dworakowska D \& Grossman AB 2009 The pathophysiology of pituitary adenomas. Best Practice and Research: Clinical Endocrinology and Metabolism 23 525-541. (https://doi.org/10.1016/j.beem.2009.05.004)

Esposito D, Olsson DS, Ragnarsson O, Buchfelder M, Skoglund T \& Johannsson G 2019 Non-functioning pituitary adenomas: indications for pituitary surgery and post-surgical management. Pituitary 22 422-434. (https://doi.org/10.1007/s11102-019-00960-0)

Esquenazi Y, Essayed WI, Singh H, Mauer E, Ahmed M, Christos PJ \& Schwartz TH 2017 Endoscopic endonasal versus microscopic transsphenoidal surgery for recurrent and/or residual pituitary adenomas. World Neurosurgery 101 186-195. (https://doi. org/10.1016/j.wneu.2017.01.110)

Feldkamp J, Santen R, Harms E, Aulich A, Modder U \& Scherbaum WA 1999 Incidentally discovered pituitary lesions: high frequency of macroadenomas and hormone-secreting adenomas - results of a prospective study. Clinical Endocrinology 51 109-113. (https://doi. org/10.1046/j.1365-2265.1999.00748.x)

Fernandez A, Karavitaki N \& Wass JA 2010 Prevalence of pituitary adenomas: a community-based, cross-sectional study in Banbury (Oxfordshire, UK). Clinical Endocrinology 72 377-382. (https://doi. org/10.1111/j.1365-2265.2009.03667.x)

Fernandez-Balsells MM, Murad MH, Barwise A, Gallegos-Orozco JF, Paul A, Lane MA, Lampropulos JF, Natividad I, Perestelo-Perez L, Ponce de Leon-Lovaton PG, et al. 2011 Natural history of nonfunctioning pituitary adenomas and incidentalomas: a systematic review and metaanalysis. Journal of Clinical Endocrinology and Metabolism 96 905-912. (https://doi.org/10.1210/jc.2010-1054)

Freda PU, Beckers AM, Katznelson L, Molitch ME, Montori VM, Post KD, Vance ML \& Endocrine Society 2011 Pituitary incidentaloma: an endocrine society clinical practice guideline. Journal of Clinical Endocrinology and Metabolism 96 894-904. (https://doi.org/10.1210/ jc.2010-1048)

Freda PU, Bruce JN, Khandji AG, Jin Z, Hickman RA, Frey E, ReyesVidal C, Otten M, Wardlaw SL \& Post KD 2020 Presenting features in 269 patients with clinically nonfunctioning pituitary adenomas enrolled in a prospective study. Journal of the Endocrine Society 4 bvaa021. (https://doi.org/10.1210/jendso/bvaa021)

Fusco A, Giampietro A, Bianchi A, Cimino V, Lugli F, Piacentini S, Lorusso M, Tofani A, Perotti G, Lauriola L, et al. 2012 Treatment with octreotide LAR in clinically non-functioning pituitary adenoma: results from a case-control study. Pituitary 15 571-578 (https://doi.org/10.1007/s11102-011-0370-8)

Galm BP, Martinez-Salazar EL, Swearingen B, Torriani M, Klibanski A, Bredella MA \& Tritos NA 2018 MRI texture analysis as a predictor of tumor recurrence or progression in patients with clinically nonfunctioning pituitary adenomas. European Journal of Endocrinology 179 191-198. (https://doi.org/10.1530/EJE-18-0291)

Gittoes NJ, Bates AS, Tse W, Bullivant B, Sheppard MC, Clayton RN \& Stewart PM 1998 Radiotherapy for non-function pituitary tumours.
Clinical Endocrinology 48 331-337. (https://doi. org/10.1046/j.1365-2265.1998.00393.x)

Greenman Y, Ouaknine G, Veshchev I, Reider II G, Segev Y \& Stern N 2003 Postoperative surveillance of clinically nonfunctioning pituitary macroadenomas: markers of tumour quiescence and regrowth. Clinical Endocrinology 58 763-769. (https://doi. org/10.1046/j.1365-2265.2003.01784.x)

Greenman Y, Cooper O, Yaish I, Robenshtok E, Sagiv N, Jonas-Kimchi T, Yuan X, Gertych A, Shimon I, Ram Z, et al. 2016 Treatment of clinically nonfunctioning pituitary adenomas with dopamine agonists. European Journal of Endocrinology 175 63-72. (https://doi. org/10.1530/EJE-16-0206)

Grossman A, Ross R, Charlesworth M, Adams CB, Wass JA, Doniach I \& Besser GM 1985 The effect of dopamine agonist therapy on large functionless pituitary tumours. Clinical Endocrinology 22 679-686. (https://doi.org/10.1111/j.1365-2265.1985.tb03004.x)

Gu YH \& Feng YG 2018 Down-regulation of TGF-beta RII expression is correlated with tumor growth and invasion in non-functioning pituitary adenomas. Journal of Clinical Neuroscience 47 264-268. (https://doi.org/10.1016/j.jocn.2017.07.033)

Guo J, Wang Z, Miao Y, Shen Y, Li M, Gong L, Wang H, He Y, Gao H, Liu Q, et al. 2019 A twocircRNA signature predicts tumour recurrence in clinical nonfunctioning pituitary adenoma. Oncology Reports $\mathbf{4 1}$ 113-124. (https://doi.org/10.3892/or.2018.6851)

Halem HA, Hochgeschwender U, Thiagalingam A \& Culler MD 2020 OR06-02 TBR-760, a chimeric somatostatin-dopamine compound, arrests aggressive non-functioning pituitary adenoma growth in vivo. Journal of the Endocrine Society 4 (Supplement 1) OR06-02. (https://doi.org/10.1210/jendso/bvaa046.895)

Ibanez-Costa A, Rivero-Cortes E, Vazquez-Borrego MC, Gahete MD, Jimenez-Reina L, Venegas-Moreno E, de la Riva A, Arraez MÁ, Gonzalez-Molero I, Schmid HA, et al. 2016 Octreotide and pasireotide (dis)similarly inhibit pituitary tumor cells in vitro. Journal of Endocrinology 231 135-145. (https://doi.org/10.1530/JOE16-0332)

Iglesias P, Arcano K, Trivino V, Garcia-Sancho P, Diez JJ, Villabona C \& Cordido F 2017 Prevalence, clinical features, and natural history of incidental clinically non-functioning pituitary adenomas. Hormone and Metabolic Research 49 654-659. (https://doi. org/10.1055/s-0043-115645)

Ilie MD, Lasolle H \& Raverot G 2019 Emerging and novel treatments for pituitary tumors. Journal of Clinical Medicine 8 1107. (https://doi. org/10.3390/jcm8081107)

Jahangiri A, Wagner J, Han SW, Zygourakis CC, Han SJ, Tran MT, Miller LM, Tom MW, Kunwar S, Blevins Jr LS, et al. 2014 Morbidity of repeat transsphenoidal surgery assessed in more than 1000 operations. Journal of Neurosurgery 121 67-74. (https://doi.org/10.317 1/2014.3.JNS131532)

Jiang X \& Zhang X 2013 The molecular pathogenesis of pituitary adenomas: an update. Endocrinology and Metabolism 28 245-254. (https://doi.org/10.3803/EnM.2013.28.4.245)

Kaltsas GA, Kola B, Borboli N, Morris DG, Gueorguiev M, Swords FM, Czirjak S, Kirschner LS, Stratakis CA, Korbonits M, et al. 2002 Sequence analysis of the PRKAR1A gene in sporadic somatotroph and other pituitary tumours. Clinical Endocrinology 57 443-448. (https://doi.org/10.1046/j.1365-2265.2002.01643.x)

Kaltsas GA, Kolomodi D, Randeva H \& Grossman A 2019 Nonneuroendocrine neoplasms of the pituitary region. Journal of Clinical Endocrinology and Metabolism 104 3108-3123. (https://doi. org/10.1210/jc.2018-01871)

Karavitaki N, Thanabalasingham G, Shore HC, Trifanescu R, Ansorge O, Meston N, Turner HE \& Wass JA 2006 Do the limits of serum prolactin in disconnection hyperprolactinaemia need re-definition? A study of 226 patients with histologically verified non-functioning pituitary macroadenoma. Clinical Endocrinology 65 524-529. (https:// doi.org/10.1111/j.1365-2265.2006.02627.x) https://erc bioscientifica com

https://doi.org/10.1530/ERC-20-0136 (c) 2020 Society for Endocrinology Published by Bioscientifica Ltd. Printed in Great Britain 
Karavitaki N, Collison K, Halliday J, Byrne JV, Price P, Cudlip S \& Wass JA 2007 What is the natural history of nonoperated nonfunctioning pituitary adenomas? Clinical Endocrinology 67 938-943. (https://doi.org/10.1111/j.1365-2265.2007.02990.x)

Karppinen A, Ritvonen E, Roine R, Sintonen H, Vehkavaara S, Kivipelto L, Grossman AB, Niemela M \& Schalin-Jantti C 2016 Health-related quality of life in patients treated for nonfunctioning pituitary adenomas during the years 2000-2010. Clinical Endocrinology 84 532-539. (https://doi.org/10.1111/cen.12967)

Komor J, Reubi JC \& Christ ER 2014 Peptide receptor radionuclide therapy in a patient with disabling non-functioning pituitary adenoma. Pituitary 17 227-231. (https://doi.org/10.1007/s11102-0130494-0)

Korevaar T, Wass JA, Grossman AB \& Karavitaki N 2012 Disconnection hyperprolactinaemia in nonadenomatous sellar/parasellar lesions practically never exceeds $2000 \mathrm{mU} / \mathrm{l}$. Clinical Endocrinology $\mathbf{7 6}$ 602-603. (https://doi.org/10.1111/j.1365-2265.2011.04226.x)

Langlois F, Lim DST, Varlamov E, Yedinak CG, Cetas JS, McCartney S, Dogan A \& Fleseriu M 2017 Clinical profile of silent growth hormone pituitary adenomas; higher recurrence rate compared to silent gonadotroph pituitary tumors, a large single center experience. Endocrine 58 528-534. (https://doi.org/10.1007/s12020-017-1447-6)

Langlois F, Woltjer R, Cetas JS \& Fleseriu M 2018 Silent somatotroph pituitary adenomas: an update. Pituitary 21 194-202. (https://doi. org/10.1007/s11102-017-0858-y)

Li A, Liu W, Cao P, Zheng Y, Bu Z \& Zhou T 2017 Endoscopic versus microscopic transsphenoidal surgery in the treatment of pituitary adenoma: a systematic review and meta-analysis. World Neurosurgery 101 236-246. (https://doi.org/10.1016/j.wneu.2017.01.022)

Lin AL, Jonsson P, Tabar V, Yang TJ, Cuaron J, Beal K, Cohen M, Postow M, Rosenblum M, Shia J, et al. 2018 Marked response of a hypermutated ACTH-secreting pituitary carcinoma to ipilimumab and nivolumab. Journal of Clinical Endocrinology and Metabolism 103 3925-3930. (https://doi.org/10.1210/jc.2018-01347)

Littley MD, Shalet SM, Beardwell CG, Ahmed SR, Applegate G \& Sutton ML 1989 Hypopituitarism following external radiotherapy for pituitary tumours in adults. Quarterly Journal of Medicine 70 145-160. (https://doi.org/10.1093/oxfordjournals.qjmed.a068308)

Losa M, Mortini P, Barzaghi R, Ribotto P, Terreni MR, Marzoli SB, Pieralli S \& Giovanelli M 2008 Early results of surgery in patients with nonfunctioning pituitary adenoma and analysis of the risk of tumor recurrence. Journal of Neurosurgery 108 525-532. (https://doi. org/10.3171/JNS/2008/108/3/0525)

Losa M, Donofrio CA, Barzaghi R \& Mortini P 2013 Presentation and surgical results of incidentally discovered nonfunctioning pituitary adenomas: evidence for a better outcome independently of other patients' characteristics. European Journal of Endocrinology 169 735-742. (https://doi.org/10.1530/EJE-13-0515)

Losa M, Bogazzi F, Cannavo S, Ceccato F, Curto L, De Marinis L, Iacovazzo D, Lombardi G, Mantovani G, Mazza E, et al. 2016 Temozolomide therapy in patients with aggressive pituitary adenomas or carcinomas. Journal of Neuro-Oncology 126 519-525. (https://doi.org/10.1007/s11060-015-1991-y)

Lucas JW, Bodach ME, Tumialan LM, Oyesiku NM, Patil CG, Litvack Z, Aghi MK \& Zada G 2016 Congress of neurological surgeons systematic review and evidence-based guideline on primary management of patients with nonfunctioning pituitary adenomas. Neurosurgery 79 E533-E535. (https://doi.org/10.1227/NEU.0000000000001389)

McCormack A, Dekkers OM, Petersenn S, Popovic V, Trouillas J, Raverot G, Burman P \& ESE Survey Collaborators 2018 Treatment of aggressive pituitary tumours and carcinomas: results of a European Society of Endocrinology (ESE) survey 2016. European Journal of Endocrinology 178 265-276. (https://doi.org/10.1530/EJE-17-0933)

Mete O \& Lopes MB 2017 Overview of the 2017 WHO classification of pituitary tumors. Endocrine Pathology 28 228-243. (https://doi. org/10.1007/s12022-017-9498-z)
Mete O, Kefeli M, Çalışkan S \& Asa SL 2019 GATA3 immunoreactivity expands the transcription factor profile of pituitary neuroendocrine tumors. Modern Pathology 32 484-489. (https://doi.org/10.1038/ s41379-018-0167-7)

Minniti G, Clarke E, Scaringi C \& Enrici RM 2016 Stereotactic radiotherapy and radiosurgery for non-functioning and secreting pituitary adenomas. Reports of Practical Oncology and Radiotherapy 21 370-378. (https://doi.org/10.1016/j.rpor.2014.09.004)

Murad MH, Fernandez-Balsells MM, Barwise A, Gallegos-Orozco JF, Paul A, Lane MA, Lampropulos JF, Natividad I, Perestelo-Perez L, Ponce de Leon-Lovaton PG, et al. 2010 Outcomes of surgical treatment for nonfunctioning pituitary adenomas: a systematic review and meta-analysis. Clinical Endocrinology 73 777-791. (https:// doi.org/10.1111/j.1365-2265.2010.03875.x)

Neou M, Villa C, Armignacco R, Jouinot A, Raffin-Sanson ML, Septier A, Letourneur F, Diry S, Diedisheim M, Izac B, et al. 2020 Pangenomic classification of pituitary neuroendocrine tumors. Cancer Cell $\mathbf{3 7}$ 123.e5-134.e5. (https://doi.org/10.1016/j.ccell.2019.11.002)

Nielsen EH, Lindholm J, Laurberg P, Bjerre P, Christiansen JS, Hagen C, Juul S, Jorgensen J, Kruse A \& Stochholm K 2007 Nonfunctioning pituitary adenoma: incidence, causes of death and quality of life in relation to pituitary function. Pituitary 10 67-73. (https://doi. org/10.1007/s11102-007-0018-x)

Nishizawa S, Ohta S, Yokoyama T \& Uemura K 1998 Therapeutic strategy for incidentally found pituitary tumors ('pituitary incidentalomas'). Neurosurgery 43 1344-1348; discussion 1348-1350. (https://doi.org/10.1227/00006123-199812000-00047)

Nomikos P, Ladar C, Fahlbusch R \& Buchfelder M 2004 Impact of primary surgery on pituitary function in patients with non-functioning pituitary adenomas - a study on 721 patients. Acta Neurochirurgica 146 27-35. (https://doi.org/10.1007/s00701-003-0174-3)

Ntali G \& Wass JA 2018 Epidemiology, clinical presentation and diagnosis of non-functioning pituitary adenomas. Pituitary $\mathbf{2 1}$ 111-118. (https://doi.org/10.1007/s11102-018-0869-3)

Ntali G, Capatina C, Fazal-Sanderson V, Byrne JV, Cudlip S, Grossman AB, Wass JA \& Karavitaki N 2016 Mortality in patients with non-functioning pituitary adenoma is increased: systematic analysis of 546 cases with long follow-up. European Journal of Endocrinology 174 137-145. (https://doi.org/10.1530/EJE-15-0967)

Olsson DS, Nilsson AG, Bryngelsson IL, Trimpou P, Johannsson G \& Andersson E 2015 Excess mortality in women and young adults with nonfunctioning pituitary adenoma: a Swedish nationwide study. Journal of Clinical Endocrinology and Metabolism 100 2651-2658. (https://doi.org/10.1210/jc.2015-1475)

O'Sullivan EP, Woods C, Glynn N, Behan LA, Crowley R, O'Kelly P, Smith D, Thompson CJ \& Agha A 2009 The natural history of surgically treated but radiotherapy-naive nonfunctioning pituitary adenomas. Clinical Endocrinology 71 709-714. (https://doi. org/10.1111/j.1365-2265.2009.03583.x)

Pagesy P, Li JY, Kujas M, Peillon F, Delalande O, Visot A \& Derome P 1991 Apparently silent somatotroph adenomas. Pathology, Research and Practice 187 950-956. (https://doi.org/10.1016/S03440338(11)81066-6)

Raappana A, Koivukangas J, Ebeling T \& Pirila T 2010 Incidence of pituitary adenomas in Northern Finland in 1992-2007. Journal of Clinical Endocrinology and Metabolism 95 4268-4275. (https://doi. org/10.1210/jc.2010-0537)

Raverot G, Dantony E, Beauvy J, Vasiljevic A, Mikolasek S, BorsonChazot F, Jouanneau E, Roy P \& Trouillas J 2017 Risk of recurrence in pituitary neuroendocrine tumors: a prospective study using a fivetiered classification. Journal of Clinical Endocrinology and Metabolism 102 3368-3374. (https://doi.org/10.1210/jc.2017-00773)

Raverot G, Burman P, McCormack A, Heaney A, Petersenn S, Popovic V, Trouillas J, Dekkers OM \& European Society of Endocrinology 2018 European Society of Endocrinology Clinical Practice Guidelines for the management of aggressive pituitary tumours and carcinomas. 
European Journal of Endocrinology 178 G1-G24. (https://doi. org/10.1530/EJE-17-0796)

Reddy R, Cudlip S, Byrne JV, Karavitaki N \& Wass JA 2011 Can we ever stop imaging in surgically treated and radiotherapy-naive patients with non-functioning pituitary adenoma? European Journal of Endocrinology 165 739-744. (https://doi.org/10.1530/EJE-11-0566)

Reincke M, Allolio B, Saeger W, Menzel J \& Winkelmann W 1990 The 'incidentaloma' of the pituitary gland. Is neurosurgery required? JAMA 263 2772-2776. (https://doi.org/10.1001/jama.1990.03440200076026)

Righi A, Faustini-Fustini M, Morandi L, Monti V, Asioli S, Mazzatenta D, Bacci A \& Foschini MP 2017 The changing faces of corticotroph cell adenomas: the role of prohormone convertase 1/3. Endocrine $\mathbf{5 6}$ 286-297. (https://doi.org/10.1007/s12020-016-1028-0)

Rizzoli P, Iuliano S, Weizenbaum E \& Laws E 2016 Headache in patients with pituitary lesions: a longitudinal cohort study. Neurosurgery $\mathbf{7 8}$ 316-323. (https://doi.org/10.1227/NEU.0000000000001067)

Salomon MP, Wang X, Marzese DM, Hsu SC, Nelson N, Zhang X, Matsuba C, Takasumi Y, Ballesteros-Merino C, Fox BA, et al. 2018 The epigenomic landscape of pituitary adenomas reveals specific alterations and differentiates among acromegaly, Cushing's disease and endocrine-inactive subtypes. Clinical Cancer Research $\mathbf{2 4}$ 4126-4136. (https://doi.org/10.1158/1078-0432.CCR-17-2206)

Sam AH, Shah S, Saleh K, Joshi J, Roncaroli F, Robinson S, Cox J, Martin NM, Mendoza N, Meeran K, et al. 2015 Clinical outcomes in patients with nonfunctioning pituitary adenomas managed conservatively. Clinical Endocrinology 83 861-865. (https://doi. org/10.1111/cen.12860)

Sanno N, Oyama K, Tahara S, Teramoto A \& Kato Y 2003 A survey of pituitary incidentaloma in Japan. European Journal of Endocrinology 149 123-127. (https://doi.org/10.1530/eje.0.1490123)

Scangas GA \& Laws Jr ER 2014 Pituitary incidentalomas. Pituitary 17 486-491. (https://doi.org/10.1007/s11102-013-0517-x)

Sjostedt E, Bollerslev J, Mulder J, Lindskog C, Ponten F \& CasarBorota O 2017 A specific antibody to detect transcription factor T-Pit: a reliable marker of corticotroph cell differentiation and a tool to improve the classification of pituitary neuroendocrine tumours. Acta Neuropathologica 134 675-677. (https://doi.org/10.1007/s00401017-1768-9)

Taelman VF, Radojewski P, Marincek N, Ben-Shlomo A, Grotzky A, Olariu CI, Perren A, Stettler C, Krause T, Meier LP, et al. 2016 Upregulation of key molecules for targeted imaging and therapy. Journal of Nuclear Medicine 57 1805-1810. (https://doi.org/10.2967/ jnumed.115.165092)

Tampourlou M, Ntali G, Ahmed S, Arlt W, Ayuk J, Byrne JV, Chavda S, Cudlip S, Gittoes N, Grossman A, et al. 2017 Outcome of nonfunctioning pituitary adenomas that regrow after primary treatment: a study from two large UK centers. Journal of Clinical Endocrinology and Metabolism 102 1889-1897. (https://doi. org/10.1210/jc.2016-4061)

Tandon V, Raheja A, Suri A, Chandra PS, Kale SS, Kumar R, Garg A, Kalaivani M, Pandey RM \& Sharma BS 2017 Randomized trial for superiority of high field strength intra-operative magnetic resonance imaging guided resection in pituitary surgery. Journal of Clinical Neuroscience 37 96-103. (https://doi.org/10.1016/j.jocn.2016.10.044)

Thakker RV, Newey PJ, Walls GV, Bilezikian J, Dralle H, Ebeling PR, Melmed S, Sakurai A, Tonelli F, Brandi ML, et al. 2012 Clinical practice guidelines for multiple endocrine neoplasia type 1 (MEN1). Journal of Clinical Endocrinology and Metabolism 97 2990-3011. (https://doi.org/10.1210/jc.2012-1230)

Tomlinson JW, Holden N, Hills RK, Wheatley K, Clayton RN, Bates AS, Sheppard MC \& Stewart PM 2001 Association between premature mortality and hypopituitarism. West Midlands Prospective
Hypopituitary Study Group. Lancet 357 425-431. (https://doi. org/10.1016/s0140-6736(00)04006-x)

Trouillas J, Roy P, Sturm N, Dantony E, Cortet-Rudelli C, Viennet G, Bonneville JF, Assaker R, Auger C, Brue T, et al. 2013 A new prognostic clinicopathological classification of pituitary adenomas: a multicentric case-control study of 410 patients with 8 years postoperative follow-up. Acta Neuropathologica 126 123-135. (https://doi. org/10.1007/s00401-013-1084-y)

Trouillas J, Jaffrain-Rea ML, Vasiljevic A, Raverot G, Roncaroli F \& Villa C 2020 How to classify the pituitary neuroendocrine tumors (PitNET)s in 2020. Cancers 12 514. (https://doi.org/10.3390/ cancers12020514)

Turchini J, Sioson L, Clarkson A, Sheen A \& Gill AJ 2020 Utility of GATA-3 expression in the analysis of pituitary neuroendocrine tumour (PitNET) transcription factors. Endocrine Pathology 31 150-155. (https://doi.org/10.1007/s12022-020-09615-4)

Vandeva S, Daly AF, Petrossians P, Zacharieva S \& Beckers A 2019 Somatic and germline mutations in the pathogenesis of pituitary adenomas. European Journal of Endocrinology 181 R235-R254. (https:// doi.org/10.1530/EJE-19-0602)

Vargas G, Gonzalez B, Ramirez C, Ferreira A, Espinosa E, Mendoza V, Guinto G, Lopez-Felix B, Zepeda E \& Mercado M 2015 Clinical characteristics and treatment outcome of 485 patients with nonfunctioning pituitary macroadenomas. International Journal of Endocrinology 2015 756069. (https://doi.org/10.1155/2015/756069)

Vázquez-Borrego MC, L-López F, Gálvez-Moreno MA, Fuentes-Fayos AC, Venegas-Moreno E, Herrera-Martínez AD, Blanco-Acevedo C, Solivera J, Landsman T, Gahete MD, et al. 2020 A new generation somatostatin-dopamine analogue exerts potent antitumoral actions on pituitary neuroendocrine tumor cells. Neuroendocrinology 110 70-82. (https://doi.org/10.1159/000500812)

Verges B, Boureille F, Goudet P, Murat A, Beckers A, Sassolas G, Cougard P, Chambe B, Montvernay C \& Calender A 2002 Pituitary disease in MEN type 1 (MEN1): data from the France-Belgium MEN1 multicenter study. Journal of Clinical Endocrinology and Metabolism 87 457-465. (https://doi.org/10.1210/jcem.87.2.8145)

Vicchio TM, Aliquo F, Ruggeri RM, Ragonese M, Giuffrida G, Cotta OR, Spagnolo F, Torre ML, Alibrandi A, Asmundo A, et al. 2020 MicroRNAs expression in pituitary tumors: differences related to functional status, pathological features, and clinical behavior. Journal of Endocrinological Investigation 43 947-958. (https://doi.org/10.1007/ s40618-019-01178-4)

Wang Y, He Q, Meng X, Zhou S, Zhu Y, Xu J \& Tao R 2019 Apatinib (YN968D1) and temozolomide in recurrent invasive pituitary adenoma: case report and literature review. World Neurosurgery 124 319-322. (https://doi.org/10.1016/j.wneu.2018.12.174)

Yu SY, Du Q, Yao SY, Zhang KN, Wang J, Zhu Z \& Jiang XB 2018 Outcomes of endoscopic and microscopic transsphenoidal surgery on non-functioning pituitary adenomas: a systematic review and meta-analysis. Journal of Cellular and Molecular Medicine 22 2023-2027. (https://doi.org/10.1111/jcmm.13445)

Zatelli MC, Minoia M, Filieri C, Tagliati F, Buratto M, Ambrosio MR, Lapparelli M, Scanarini M \& Degli Uberti EC 2010 Effect of everolimus on cell viability in nonfunctioning pituitary adenomas. Journal of Clinical Endocrinology and Metabolism 95 968-976. (https:// doi.org/10.1210/jc.2009-1641)

Zhenye L, Chuzhong L, Youtu W, Xiaolei L, Lei C, Lichuan H, Hongyun W, Yonggang W, Fei W \& Yazhuo Z 2014 The expression of TGF-beta1, Smad3, phospho-Smad3 and Smad7 is correlated with the development and invasion of nonfunctioning pituitary adenomas. Journal of Translational Medicine 12 71. (https://doi. org/10.1186/1479-5876-12-71)

Received in final form 11 June 2020

Accepted 15 July 2020

Accepted Manuscript published online 15 July 2020 https://erc.bioscientifica.com https://doi.org/10.1530/ERC-20-0136 (c) 2020 Society for Endocrinology Published by Bioscientifica Ltd. Printed in Great Britain 